\title{
The "Geography of Hunger" legacy
}

At worldwide level, every year are released conventional books, planchettes, memories of scientific and cultural events and the latest are, electronics texts, hundreds of thousands of publications saturating the universe of readers or in a reduced scale, a more restricted and captive audience characterized by a particular interest. In the midst of this diversity, some texts escaped the wearing of time and earned some reprints or even were updated which resulted in a short or long duration of survival, some even by the transcendence character, as for the example of sacred books. Exceptionally, other publications often reflect their own ephemerality mark, because they do not propose more permanent goals, which eventually would earn the status of longevity that characterizes the classical books.

This introductory approach seems to be appropriate in understanding the itinerary of the "Geography of Hunger", now at its 70th anniversary and with 11 editions in Portuguese, in addition to 25 translations in the most spoken languages in the world and even the extinct language as the ancient Sanskrit. It is not believed, aside from the Holy Scriptures, that any other written publication has reached the 21 st century with such massive readers.

It is interesting, even in the way of notifying another originality, to make a brief retrospect about the author. Josué de Castro, a recently graduated physician, had a rich and crucial experience as a clinical physician in a major industry in Recife, Brazil. At that time he noted that the workers' "basal disease" was hunger, clinically expressed as anemia, vitamin A deficiency, protein-calorie malnutrition (nowadays it is Protein Energy Malnutrition-PEM), complex B deficiencies and other qualitative and quantitative manifestations of insufficient feeding.

Based on these observations by a working professional, he had the historic ambitious idea to make the first survey based on the working class' living conditions in Recife, researching 800 workers' families at manufacturing companies in three neighborhoods of the city. In addition to food intake and its analysis in macro and microelements terms, he elaborated, based on concrete data, the first basic food basket for the Brazilian families, by evaluating food, housing, schooling, transportation, clothing and health expenses. In other words, an entire context on the urban workers' family budgets.

The report of this survey was published as a provincial booklet and the bureaucracy Diário Oficial do Estado de Pernambuco (Official Gazette of Pernambuco State), along with drugstores advertisements and other diverse establishments to purchase and sell goods. ${ }^{1}$ Definitely it was not the place for a scientific publication. But the work was done, covering 800 families with more than 3.000 people (a sample size that would until today be statistically consistent) was released in five small tables and by accumulating other experiences by the author himself, research on the Universal History, books on anthropology, sociology and political economy, new and systematic readings on food and nutritional issues in the world, and embodied as the classic "Geography of Hunger". 2

This historic recovery should be properly valued. Josué de Castro was a man of intense political militancy and intellectual, and thanks to his performance, The Geography of Hunger and its antecedents had striking historical ramifications, such as the establishment of the minimum wage in Brazil (even nowadays the main measurement on food and nutritional policy in the country), the creation of the Campanha Nacional de Merenda Escolar (National School Meal Program Campaign), (which is the most extensive and consolidated support program by Brazil and Latin America public power), the popular restaurants of Serviço de Alimentação da Previdência Social (SAPS) (Social Providence Food Service), The iodizing of salt for home use to prevent endemic goiter, composition of laboratory studies on Brazilian food, a pioneer course on Nutrition by the former University of Brazil, the Comissão Nacional de Alimentação (CNA), (National Supply Committee), the inclu- 
sion of food and nutrition teaching courses from the Ministry of Health and other great political, administrative and social initiatives development. 3

The Geography of Hunger became a paradigmatic and doctrinal book. As a paradigm, it defines an approach of problems as food, nutrition and related areas that until today is a population-based study in various parts of the world. As a doctrine, conceives and consolidates with the participation of other scholars and thinkers, especially nucleated at the University of Paris 8 , a comprehensive vision and proposals for solutions on holistic current and future problems in the world. This is called the human development, multiple process, simultaneous and interdependent world of economic, social, political, cultural, ethical, ecological and co-participants values, including their own subjectivity and the spirituality cult of various people and various people in the world. 4

It is without reason, that over 40 years ago, Josué de Castro received subsequently, three nominations for the Nobel Prize (one for Medicine, and two for Peace), chosen by a public poll in France as one of the 20 citizens in the world. A public man and writer, André Malraux, believed that Josué de Castro was one of the four characters who most influenced the ideas and movements for changes in the $20^{\text {th }}$ century. And, certainly, The Geography of Hunger is an important part of this legacy.

Recognizing the dimension de Josué de Castro as a physician and a social scientist, the Revista Brasileira de Saúde Materno Infantil (Brazilian Journal of Mother and Child Health), by its own philosophy and scope, welcomes studies on populations not only from Brazil, but from Latin American countries in the same social contexts investigated by the eminent professor, which will never be an exaggeration to pay him a tribute like this. And for the same reason, the Instituto de Medicina Integral Prof. Fernando Figueira (IMIP), the Publisher House and the sponsors of the Journal, feel a great honor to be associated to everyone who dedicated a tribute to the greatest professor on his remarkable book celebrating its $70^{\text {th }}$ anniversary.

\section{References}

1. Castro J. As condições de vida da classe operária no Recife: estudo econômico de sua alimentação. Recife, Imprensa Oficial; 1932.

2. Castro J. Geografia da Fome - A Fome no Brasil. Rio de Janeiro: Gráfica "O Cruzeiro" S.A - Brasil; 1946. 354 p.

3. Ferro F. L'héritage politique, parlamentaire et institutionnel de Josué de Castro au Brésil. In Bué A. et Plet F. Alimentation, environnement et santé. Pour un droit à l'alimentation. Pàris: Ellipses Ed; 2010. p. 97-102.

4. Bué A, Zanoni M. L'ouvre de Josué de Castro: un pensée globale et géopolitique de la faim et de l'écologie politique. In Bué A. et Plet F. Alimentation, environnement et santé. Pour un droit à l'alimentation. Pàris: Ellipses Ed; 2010. p. 17-28.

Malaquias Batista Filho 1

José Arlindo Soares 2

1 Professor and Researcher at the Instituto de Medicina Integral Professor Fernando Figueira (IMIP).

2 Sociologist and former President of Josué de Castro Study Center. 